\title{
National Treatment in International Trade and Investment Law ${ }^{1}$
}

\author{
ION GÂLEA - BOGDAN BIRIŞ
}

\begin{abstract}
The objective of the study is to make a comparison between the standard of national treatment in international investment law and the standard of national treatment in WTO law. Even if similar issues may appear under EU law, the focus of this study is international investment law and WTO law. We will look at international treaties, legal writings and judicial sources (arbitral awards, and panel or Appellate body decisions) in order to establish the similarities and differences are between the two standards of treatment. The study will aim to provide a clear analysis of article 3 paragraphs 1-3 of GATT (General Agreement on Tariffs and Trade) as well as different provisions contained in investment treaties, in reference to the standard of national treatment. The study hopes to offer some guidance on how the two standards of treatment relate to one another, which could prove very helpful for different national and international organizations and institutions when negotiating Investment Treaties or Free Trade Agreements.
\end{abstract}

Keywords: Investment, trade, non-discrimination, national treatment, K33 (International Law)

\section{INTRODUCTION. WHY DO STATES CHOOSE TO ENTER INTO TRADE AND INVESTMENT TREATIES?}

In today's world, both capital-exporting and capital-importing countries are interested in providing a smooth flow of capital, goods, services, and technologies that would ultimately benefit their economies and their people. While developed economies provide the capital base, know-how, and adequate technologies, less developed economies provide the labor force, cheap cost of establishment, and generally the underdeveloped non-consumer oriented market (Lester 2008: 3-45). ${ }^{2}$ Therefore, it is not hard to imagine the potential opportunities in expanding global trade and investment among nations, especially in regions and in sectors where returns are significantly high. While most critics will argue that Trade and Investment Agreements is a tool for rich states to spread their economic influence around the globe at the expense of less developed states, reality has shown that such agreements are to a large extent responsible for the level of economic growth seen in the majority of economies today (Lester 2008: 27-33). ${ }^{3}$

1 This work was by a grant of the Romanian National Authority for Scientific Research, CNCSUEFISCDI, project number PN-II-RU-TE-2012-3-0355.

2 See generally Lester et al. 2008: 3-45.

3 Ibid. 27-33.

Ion Gâlea, Lecturer, Ph.D., Faculty of Law, University of Bucharest, Romania, E-mail: ion.galea@ drept unibuc.ro

Bogdan Biriş, Research Assistant, Faculty of Law, University of Bucharest, Romania, E-mail: biristobo@yahoo.com

(Received: 29.01.2014; revision received: 31.03.2014; accepted: 15.04.2014.) 
For centuries, matters regarding investment and trade alongside transit, passage, fisheries and liberty of conscience have been addressed in treaties of friendship, commerce and navigation (FCN) concluded between the major powers of the time. The first ever treaty concluded by the United States was the 1778 FCN Treaty with France, and the practice remained relevant up until the advent of World War Two (WWII). After WWII, the emphasis shifted slightly from bilateral to Multilateral Agreements (DiMascio-Pauwelyn 2008: 4; Baetens 2013) ${ }^{4}$ with the aim of bringing down global barriers to trade, thus facilitating the movement of capital and services across international borders. States found that entering into such treaties would better serve their national interest by safeguarding their goods, capital and nationals from arbiter measures implemented by other states (DiMascioPauwelyn 2008: 5). ${ }^{5}$

\section{NATIONAL TREATMENT IN TRADE LAW}

\section{National Treatment under WTO - The Law}

In the WTO context, national treatment provisions are to be found in Art. III of GATT that reads: "The products of the territory of any contracting party imported into the territory of any other contracting party shall be accorded treatment no less favorable than that accorded to like products of national origin in respect of all laws, regulations and requirements affecting their internal sale, offering for sale, purchase, transportation, distribution or use". ${ }^{6}$ The purpose of this provision is to be found less in the concerns that the original drafters might have had in respect to trade flows but rather, as summarized by the Appellate Body, in the competitive opportunities afforded to imported products. "Article III protects expectations not of any particular trade volume but rather of the equal competitive relationship between imported and domestic products" (Diebold 2014: 140-171). ${ }^{7}$ Establishing when an internal tax or regulation contravenes the wording of Art. III is no easy feat. Over the years, both the Panel and Appellate Body have battled the meaning of "like products" while trying to find the ultimate test to determine which products may be considered alike for the purpose of Art. III (Diebold 2014: 140-171). ${ }^{8}$

The first challenge in crafting a good-for-all test is represented by the very nature of Art. III. The content of the article is split between a number of paragraphs. Of these, only paragraphs 1,2, 4 are relevant to this paper. Whilst paragraph 1 is more of a declaration of intent and, as such, is not binding in character, paragraphs 2 and 4 contain substantive norms and are legally binding. Paragraph 2 provides the National Treatment rules for tax measures. A complainant alleging a violation of Art. III 2 has two possible routes open to him. On the one hand, he may argue that both domestic and imported products are alike, and the imported products were taxed in excess of the domestic products. On the other hand, he may contend that the two products, are directly competitive and substitutable, and

${ }^{4}$ DiMascio-Pauwelyn 2008: 4; generally, Baetens 2013.

5 Ibid. 5.

${ }^{6}$ General Agreement on Tariffs and Trade (GATT), infra note 37, Art. III 4 (emphasis added) available at www.wto.org/english/docs_e/legal_e/gatt47_e.pdff, last visited 10.10.2013;

7 Appellate Body Report, Japan-Taxes on Alcoholic Beverages, WT/DS8/AB/R, WT/DS10/ $\mathrm{AB} / \mathrm{R}, \& \mathrm{WT} / \mathrm{DS} 11 / \mathrm{AB} / \mathrm{R}$ (adopted Nov. 1, 1996), para. 15.

8 Diebold 2014: 140-171. 
were unevenly taxed "so to afford protection to domestic products". ${ }^{9}$ Bringing forward this argument is possible because in WTO practice, "like products" are not necessarily the same as "directly competitive and substitutable products" (hereinafter DCS products). In Korea - Taxes on Alcoholic Beverages, the Panel found that like products are a subset of DCS products. ${ }^{10}$ When making a ruling on an Art. III 2 violation, either the Panel or Appellate Body might be asked to distinguish between the two categories of products.

In contrast to paragraph 2, paragraph 4 provides National Treatment rules in reference to internal regulations. Its wording is slightly more precise and less open to interpretation. Instead of setting forth two distinct obligations, like paragraph 2 does, paragraph 4 sets forth just one: imported products are not to be given less favorable treatment then domestic like products.

\section{“Likeness" under WTO Law}

Determining likeness for the purpose of Art. III is a complicated undertaking. This is due to the wording of the article which sets different standards according to the different sections of the article. Below, is a short analysis of each section in order to better understand the differences in language and meaning?

Article III 2, first sentence, sets forth a narrow standard of likeness. It is usually applied to closely related products in terms of both characteristics and end-use. Once two products or two groups of products are found to have similar physical characteristics and the same end-use, they are deemed to be like products. Additionally, consumer preference or tariff classification may also play a part, but usually the first two criteria will suffice. In the Japan-Alcoholic Beverages, the Panel was asked to determine whether shochu (domestic) and vodka (imported) are alike. By examining their physical characteristic and end-use the Panel concluded that the two products were alike and Japan was found to infringe on the national treatment provisions because it taxed the imported product in excess of respective domestic ones (Diebold 2014: 103-105). ${ }^{11}$

Article III 2 second sentence, sets a somewhat boarder standard. If two groups of products do not fall into the category of like products, then they might qualify under the category of directly competitive or substitutable products. This is a broader category comprising of products that share common end-use but differ in terms of physical characteristics. In Japan-Alcohol, the Appellate Body found that "the objective criterion in order to determine whether two products are directly competitive or substitutable products is whether they have common end-use, inter alia, as shown by the elasticity of substitution". ${ }^{12}$

Article III 4 switches back to the term "like products". In finding whether two groups of products fall under this category, the Appellate Body looked beyond the objective criteria cited above, and determined the nature and extent of the competitive relationship among products. In its reasoning, the Appellate Body was careful to point out the differences in both language and purpose, between paragraphs 2 and 4 . While both refer to "like products", the former also refers to directly competitive or substitutable products. The scope of the two paragraphs is different. The former is concerned with measures relating to taxation, while the latter addresses internal regulations. The Appellate Body concluded by saying that "the

9 GATT Art. III.

10 Appellate Body Report, Korea-Taxes on Alcoholic Beverages, WT/TS75, 84/ AB/R, para.18.

11 Diebold 2014: 103-105; Japan-Taxes on Alcoholic Beverages, supra, note 8.

12 Appellate Body Report, Japan-Alcohol, para 25 (indentation added). 
product scope of Art. III 4, although broader than the first sentence of Art. III 2, is certainly not broader the combined product scope of the two sentences of Art. III 2 of the GATT 1994". ${ }^{13}$

\section{National Treatment under WTO - The Test}

In order to assess whether an internal tax or regulatory measure will undermine equal competition opportunities between domestic and imported products, both the Panel and Appellate Body tried to develop a test that would clearly show when two categories of products may be considered sufficiently alike under the provisions of Art. III.

This is a two-step test (DiMascio-Pauwelyn 2008: 7). ${ }^{14}$ First, the Panel will have to determine if both foreign and domestic products share enough similarities in terms of physical characteristics, end-use, consumer behavior, tariffs classification and market opportunities to be considered either like products or, directly competitive or substitutable products. Second, the Panel must establish if the applied measure:

a) will tax the imported products in excess of domestic like products or,

b) is enacted so as to afford protection to domestic products $o r$,

c) affords the imported products less favorable treatment than it gives to the domestic products. $^{15}$

If any of the above-mentioned is found to be true, the measure is found discriminatory in nature, and hence a violation of Art. III. ${ }^{16}$ In practice, the tests employed by the Dispute Settlement Body (hereinafter DSB) were inconsistent. Initially, a breach of the national treatment provision was found only in those cases where the measure enacted was openly discriminatory (i.e. the measure was aimed solely at foreign products and did not cover domestic products). As globalization took hold in the late $80 \mathrm{~s}$ and early $90 \mathrm{~s}$, more and more complaints about less overt discriminatory practices, were lodged with the DSB. As a result, both the Panel and Appellate Body began employing much less permissive tests, like the "aims and effect" test, which implied a degree of intent when enacting the discriminatory measure or regulation (Lester 2008: 285). ${ }^{17}$ More recently however, the DSB scraped the "aims" but retained the "effects" test, meaning that for an infringement of Art. III to exist, the measure or regulation applied will need to have a visible negative effect on the competitive opportunities among two groups of like products, one domestic and the other imported, in favor of the domestic one. Intent is no longer required or necessary. There is however, an exception to the "effects" test in the form of Art. III 2's first sentence. It applies irrespective of whether there is an adverse effect on the competitive relation among two groups of products, if the imported products were taxed in excess of domestic like products.

13 Appellate Body Report, European Communities-Measures Affecting Asbestos and Asbestos Containing Products, Adopted 5 April, WT/DSI35/AB/R.

14 DiMascio-Pauwelyn 2008: 7.

15 GATT Art. III.

16 Appellate Body Report, Korea-Measures Affecting Imports of Fresh, Chilled and Frozen Beef, WT/DS161/AB/R (Dec. 11, 2000) (adopted Jan. 10, 2001), para. 133.

17 Lester et al. 2008: 285; GATT Panel Report, United States-taxes on Automobiles (unadopted) DS31/R. 


\section{NATIONAL TREATMENT IN INVESTMENT LAW}

"Each Party shall accord to investors of the other Party treatment no less favorable than that it accords, in like circumstances, to its own investors with respect to the establishment, acquisition, expansion, management, conduct, operation, and sale or other disposition of investments in its territory."18

Provisions regarding national treatment stem from a variety of sources, but most can be found in Bilateral Investment Treaties and Regional Trade Agreements. ${ }^{19}$ In the OECD Draft Convention on a Multilateral Agreement on Investment, the principle of national treatment is defined as the obligation of the host country to accord to foreign investors and their investments "treatment no less favorable than the treatment it accords in like circumstances to its own investors with respect to the establishment, acquisition, expansion, operation, management, maintenance, use, enjoyment and sale or other disposition of investments". As noted above, the language is somewhat different from the language used in WTO law. "Like products", was replaced by "like circumstances".

\section{"Likeness" in Investment Law}

Determining likeness in investment law can be as difficult as in trade law. Arbitral tribunals employ different methods in order to establish whether the foreign and the domestic investors are placed in a comparable setting, or, in "like circumstances". Furthermore, the scope of activities which must be compared remains controversial. In Feldman vs. New Mexico "like circumstances" was found to refer to the business sector, whilst in SD Myers vs. Canada, "like circumstances" was interpreted to mean all circumstances relevant to an economic and business sector. "The concept of "like circumstances" invites an examination of whether a non-national investor complaining of less favorable treatment is in the same "sector" as the national investor. The Tribunal takes the view that the word "sector" has a wide connotation which includes the concepts of "economic sector" and "business sector". ${ }^{20}$ In contrast, in Occidental vs. Ecuador, the tribunal referred to domestic producers in general, reasoning that this could not have been possible if it only examined the sector in which the particular activity was undertaken. ${ }^{21}$

A question often raised in the last two decades is whether WTO jurisprudence and law should bear any relevance in determining "like circumstances". At first, the answer seemed to be yes. The earlier NAFTA decisions in S. D Myers vs. Canada, Pope \& Talbot vs. Canada $^{22}$ and Feldman vs. Mexico, ${ }^{23}$ had been guided, to some extent, by WTO jurisprudence on "like products". The trend has been reversed in recent years by a number

18 See the 2012 US Model BIT. Art. 3, document available at www.state.gov/documents/ organization/188371.pdf, last visited 12.10.2013.

19 See also the North American Free Trade Agreement (NAFTA) Art. 102 available at www. ustr.gov > Trade Agreements > Free Trade Agreements, last visited 11.10.2013.

20 SD Myers v. Canada, Partial Award, 12 November 2000, 40 ILM 1408, para. 250.

21 Occidental Exploration and Production Company v. Ecuador, Award of 1 July 2004, (UNCITRAL Arbitration), London Court of International Arbitration Administered Case No. UN 3467, para. 173.

22 Pope\&Talbot c. Canada, UNCITRAL (NAFTA), 22 ILR 316, Award of 10 April 2001, paras 45-63, 68-69.

${ }^{23}$ Marvin Feldman v. Mexico, ICSID, Case no. ARB(AF)/99/1, Award of 16 December 2000, para. 165 . 
of arbiter awards, beginning with Occidental vs. Ecuador, which found that the purpose of national treatment in an investment context is rather the opposite of that under GATT/ $\mathrm{WTO}^{24}$

\section{Non-discrimination}

In the investment context, discrimination exists where investors or investments, in like circumstance, are given less favorable treatment than domestic investors or investments (Maniruzzaman 1998: 59; Newcombe-Paradell 2009: 347). ${ }^{25}$ Arbitral tribunals have to determine whether the treatment given to the foreign investor is at least as favorable as the treatment given to domestic investors. If the treatment received is less than favorable, the foreign investor may have been discriminated against. The applicability of national treatment provisions should therefore be viewed in the context of non-discrimination. ${ }^{26}$ Non-discrimination is a well-established standard of protection in international law (GarciaAmador, 1984: 285; Browlie 1983: 81). ${ }^{27}$ The non-discrimination standard does not require all treatment to be identical, but any difference in treatment must be justified on reasonable grounds. Discrimination based solely on nationality is a violation of international law (Beveridge 2000: 285). ${ }^{28}$

\section{National Treatment - The Test}

First, the Tribunal will have to determine whether the foreign and domestic investors are placed in a comparable setting, or, in "like circumstances". Second, the Tribunal must establish if the measure in question affords the foreign investor less favorable treatment than it affords domestic investors. Not all differences in treatment are discriminatory per se. Some may arise as a result of implementing measures that serve a valid regulatory purpose. Governments have the right to prescribe, within the limits of their Constitution, reasonable regulations necessary to protect the lives, health and welfare of the community, preserve good order and public morals and restrain and punish of crime. A state has the right to enforce legislation for the purpose of protecting and preserving its sovereignty and ensuring the public welfare of its citizens, even if that negatively impacts on the foreign investor and

24 Occidental Exploration and Production Company v. Ecuador, supra note 22, para. 173, "[the national treatment] is to avoid exporters being placed at a disadvantage in foreign markets because of the indirect taxes paid in the country of origin, while in GATT/WTO the purpose is to avoid imported products being affected by a distortion of competition with similar domestic products because of taxes and other regulations in the country of destination".

25 Maniruzzaman 1998: 59; Newcombe-Paradell 2009: 347.

${ }^{26}$ Lauder v. Czech Republic, UNCITRAL, Award of 3 September 2001 para. 220.

27 Garcia-Amador 1984: 285; Browlie 1983: 81; Banco Nacional de Cuba v. Sabbatino, US (2d Cir. 1962), 845, 867; BP Exploration Company (Libya) Limited v. Libya, Award, 10 October 1973, 53 ILR. 297, 329.

28 The Restatement (Third) - The Foreign Relations Law of the United States, The American Law Institute (1986), 1-488, vol. I, Section 712; Case concerning the Barcelona Traction, Light and Power Company (Second Phase), Judgment of 5 February 1970, ICJ Reports 1970; Beveridge 2000: 285. 
his investment. This view is held by both state practice ${ }^{29}$ and jurisprudence. ${ }^{30}$ Other situations where a potential danger of imperilment is to be found are those where "the foreign interest exercising control $[\ldots]$ might take action that threatens to impair the national security, national defense, or the existence of a serious presumption that the investor will possibly commit specific listed crimes such as drug trafficking, corruption, terrorism or money laundering". ${ }^{31}$

\section{COMPARING NATIONAL TREATMENT STANDARDS}

\section{The Common Core}

The two standards of National Treatment share some important similarities as well as differences. In this section of the paper we will concentrate on the similarities among the standards.

The first similarity is the obligation not to discriminate. The principle of nondiscrimination is, in itself, a jus cogens norm of customary international law. By inserting this principle in both investment and trade treaties meant it could now be enforced under both treaty and customary law. Both de jure and de facto discrimination are covered. There is, however, a dispute among prominent experts and scholars, on whether such a standard might include other forms of discrimination, such as racial discrimination. The answer to that question is no. In the trade and investment context, this standard has been interpreted to mean that the national treatment provision covers only discrimination based on nationality and not on race, sex, religion, social status etc. (DiMascio-Pauwelyn 2008: 23). ${ }^{32}$

The second similarity refers to the existence of a nexus. An in-depth analysis would likely show that this could be considered as much of a similarity, as of a difference, especially if we consider the rule set forth by Art. III 2, first sentence. But overall, national treatment provisions require the existence of a nexus between the measures enacted and the negative effects that are produced. To have standing, an aggrieved state or investor, must prove that such a nexus exists and that its rights were impaired. Without the existence of such a nexus, tribunals would generally be unable to find an infringement of the national treatment provisions.

A third similarity relates to regulatory measures. It is important to notice that not all challenged measures are discriminatory per se. Some are part of the regulatory context. In both trade and investment, legitimate government concerns allow states to implement measures deemed necessary to protect their populous and economies from such risks as disease, pollution, chemical, biological and nuclear hazards, economic defaults etc. Of

${ }^{29}$ Exon-Florio amendment, Omnibus Trade and Competitiveness Bill of 1988, section 5021 (Pub. L. No. 100-418, 102 Stat. 1107; 50 U.S.C. App. § 2170); EUROPEAN UNION, Directive 94/22/EC of the European Parliament and the Council of 30 May 2004 on the conditions for granting and using authorizations for the prospection, exploration and production of hydrocarbons, Official Journal L 164, 30 June 1994, 3-8;

30 Court of Justice of the European Communities, Association Église de Scientologie de Paris \& Scientology International Reserves Trust v. the Prime Minister of the Republic of France, C-54/99, ECR [2000] I-01335, para 18-26.

31 Marvin Feldman v. Mexico, supra, note 25.

32 DiMascio-Pauwelyn 2008: 23. 
course, such measure cannot, and should not be arbitrary, ${ }^{33}$ and should not offer protection to domestic goods and investors in detriment to their foreign counterparts. Intent is neither required nor necessary. In WTO law, non- protectionist regulatory exceptions are to be found in Art. XX of GATT which reads “... nothing in this Agreement shall be construed to prevent the adoption or enforcement by any contracting party of measures: (a) necessary to protect public morals; (b) necessary to protect human, animal or plant life or health [....] (i) involving restrictions on exports of domestic materials necessary to ensure essential quantities of such materials to a domestic processing industry...etc." The aforementioned exceptions are part of a list that is limited in content and purpose. In contrast, investment law operates with broader list of exceptions, usually drawn from state practice, which reflects at least to some extent, customary international law.

\section{The Differences}

Trade and investment tribunals employ different concepts of "likeness" and "less favorable treatment". "Likeness" under WTO law, is more concerned with the negative effect on the competitive relation between two distinct groups of products. Like products, are defined as products that share some sort of competitive relation in the market place. In contrast, "likeness" in investment law is linked to circumstances, and, is concerned with the impact a discriminatory measure might have on the foreign investor, rather than on competition. "Like circumstances" are to be found where both foreign and domestic investors operate in the "same economic or business sector", yet receive differential treatment.

Another difference lies in how trade and investment tribunals asses "less favorable treatment". In WTO jurisprudence, an evaluation is made on the uncompetitive effect such treatment would have on an entire group of foreign like products, in comparison to domestic like products. In contrast, investment tribunals have often found less favorable treatment to exist where a single foreign investor is treated differently to any single domestic investor, operating in like circumstances, and, irrespective of the competitive relationship between them. ${ }^{34}$ WTO law is more concerned with competitive opportunities in the market place, rather than actual trade flows. As such, it will focus on quantifying the negative effects a differential measure would have on the competitive relation between foreign and domestic products. In comparison, investment law will focus on affording the foreign investor the necessary protection against discriminatory regulations in the host country. Investment tribunals will examine the nexus between the challenged measure and the negative impact on the investment before determining whether an infringement of national treatment provisions took place.

Last but not least, there is the question of whether the two standards have direct effect (Craig-de Burca 2011) (35 $^{35}$ under domestic law. In the majority of countries, Romania included, WTO law is not granted direct effect meaning that private entities will not be allowed to resort to the rights and obligations that arise out of national treatment provisions.

33 Appellate Body Report, United States - Standards for reformulated and Conventional Gasoline, WT/DS2/AB/R (adopted May 20, 1996); The Chapeau will prohibit the application of any measure that would constitute: a) arbitrary discrimination; b) unjustifiable discrimination $c$ ) disguised restriction on international trade.

${ }^{34}$ Pope\&Talbot Inc v. Canada, supra, note 24.

35 Craig, P.--de Burca, G.: EU Law. Text, Cases and Materials, 5th ed., Oxford University Press, 2011 , chapter 7 . 
Only states may invoke breaches to the national treatment standard (Bossche 2008: 6167). ${ }^{36}$ In contrast, investment agreements allow for direct affect. Individuals can invoke their rights under those treaties, and national and international courts can invalidate domestic legislation which conflicts with the provisions of national treatment. ${ }^{37}$

\section{CONCLUSION}

Historically, investment and trade agreements have focused on different, yet complementary, objectives. Trade treaties dealt mainly with trade flows, seeking to liberalize market access for foreign goods and services and encouraging the development of trade relations. In contrast, investment treaties have been more preoccupied with protecting the inflow of capital, technology, and know-how from industrialized countries into the developing world. Each body of law developed a set of rules and principles to better serve their intended purpose. While some rules are common to both, the interpretation given to them is often different. This seems to be the case with national treatment provisions. Trade law is concerned with opportunities regarding competition and market access, and, as such, trade tribunals will examine if two distinct groups of like products, in direct competition with each other, will be offered the same level of treatment or be discriminated against based on their origin. In contrast, investment law is meant to offer protection to the foreign investor against arbitrary measures imposed by the host state. As such, investment tribunals will look to see if the treatment accorded to the foreign investor is by any means less favorable, than the treatment accorded to any individual domestic investor.

The present study examines the complementary nature of the relationship between the two standards and hopefully will offer some guidance on their applicability in practice. This may prove helpful when various national and international organizations or institutions negotiate Investment and Free Trade Agreements.

\section{REFERENCES}

Baetens, F. (ed.) (2013): Investment Law within International Law. Integrationist Perspectives. Cambridge: Cambridge University Press.

Beveridge, F. (2000): The Treatment and Taxation of Foreign Investment under International Law, Towards International Disciplines. Manchester: Manchester University Press.

van den Bossche, P. (2008): The Law and Policy of the World Trade Organization, Text, Materials and Cases. 2nd ed. New York: Cambridge University Press.

Browlie, I. (1983): System of the Law of Nations. New York: Oxford University Press.

Craig, P.-de Burca, G. (2011): EU Law. Text, Cases and Materials. 5th ed. New York: Oxford University Press.

Diebold, N. F. (2014): Non-Discrimination in International Trade in Services. 'Likeness' in WTO/ GATS. Cambridge: Cambridge University Press.

DiMascio, N.-Pauwelyn, J. (2008): Nondiscrimination in Trade and Investment Treaties: Worlds Apart or Two Sides of the Same Coin? American Journal of International Law 102(1): 48-89.

Fiona, B. (2000): The Treatment and Taxation of Foreign Investment under International Law, Towards International Disciplines. Manchester: Manchester University Press.

36 van den Bossche, P.: The Law and Policy of the World Trade Organization, Text, Materials and Cases, 2nd ed., Cambridge University Press, New York, 2008, 61-67.

372012 US Model BIT. Art. 24 document available at www.state.gov/documents/ organization/188371.pdf, last visited 12.10.2013. 
Garcia-Amador, F. V. (1984): The Changing Law of International Claim. New York: Oceana Publications.

Lester, S. et al. (2008): World Trade Law-Text, Materials and Commentary. Oxford-Portland: Hart Publishing.

Maniruzzaman, F. M. (1998): Expropriation of Alien Property and the Principle of Non-Discrimination in International Law of Foreign Investment: An Overview. Journal of Transnational Law and Policy 8(1): 57-77.

Newcombe, A.-Paradell, L. (2009): Law and Practice of Investment Treaties. Standards of Treatment. Alphen aan den Rijn: Kluwer Law International. 